\title{
Complete Settlement Disputes to Content of the Mining Divestment Agreement (Case Study of Indonesian Government and Newmont Nusa Tenggara in Arbitration)
}

\author{
Uyan Wiryadi \\ Student at Doctoral Program of Law \\ Universitas Borobudur \\ Jakarta, Indonesia \\ uyan.wiryadi@gmail.com
}

\author{
Faisal Santiago \\ Universitas Borobudur \\ Faculty of Law \\ Jakarta, Indonesia \\ faisalsantiago@gmail.com
}

\begin{abstract}
One area of concern to foreign investors in terms of investing in Indonesia is the mining sector. To that end, the government seeks to direct and manage the natural resources that are included in the mining business field. Mining business fields include petroleum, natural gas, coal, metals, tin, iron ore, bauxite, iron sand, silver and copper concentrates. "Cooperating with foreign parties, primarily through international contracts, the national interest becomes a key consideration. Indonesia has entered into a contractual agreement with foreign companies International contracts also have a dispute over understanding between the Parties One of the breaches of the Contract of Work Agreement between the Government of Indonesia and PT Newmont Nusa Tenggara (hereinafter referred to as PT NNT) The establishment of a work contract between the Government of Indonesia and PT NNT refers to Law No. 11 of 1967 on the Basic Provisions of Mining, and now following the renewal of the law, its regulation under the Law of the Republic of Indonesia Number 4 Year 2009 concerning Mining of Minerals and Coal One of the clauses in the Contract a between the Government of Indonesia and PT.NNT as contained in article 24 paragraph 3 of the contract of work that PT. NNT must ensure that shares owned by foreign investors will be offered for sale or publication, firstly to the government and second (if the government does not accept the offer within 30 days of the offer date), to Indonesian citizens or Indonesian companies controlled by Indonesian citizens. In reality the contents of the agreement relating to clauses in the Contract of Work Agreement concerning the divestment of shares for the Indonesian government gradually is not working properly, where the mining company fails to perform the divestment obligation of shares in accordance with the agreement of Contract of Work which has been agreed. This has led to disputes between the two parties, with the Government of Indonesia bringing the settlement of the matter to the Arbitration Institute.
\end{abstract}

Keywords-dispute settlement, default, divestment

\section{INTRODUCTION}

One area of concern to foreign investors in terms of investing in Indonesia is the mining sector. "The mining business sector is one of the priority business fields of the government before and after the issuance of the Investment
Law, both for foreign parties and domestic parties. To realize the various investments on December 2, 1986 the Government of Indonesia entered into a Contract of Work with PT Newmont Nusa Tenggara (PT NNT) where in the formation of such contract refers to RI Law No. 11 of 1967 on Basic Provisions of Mining, but in its implementation, PT NNT can not perform obligations in the Contract of Work which have been agreed, so in the case of default, the Government of Indonesia takes the case to the United Nations Commission on International Trade Law (UNCITRAL)).

\section{RESEARCH METHODS}

The paper is structured using the type of normative juridical research, ie research focused on assessing the application of positive legal principles. Normative juridical is an approach that uses positivist legit conception. This research uses approach of legislation and case approach.

The specification used is descriptive research specification that is a research that aims to provide a concrete description or explanation of the object or problem under study without taking conclusions in general.

In this study it is generally distinguished between data obtained directly from the public and library materials. Obtained directly from the community is called primary data (or baseline data), whereas those obtained from library materials are commonly called secondary data.

The results are presented in the form of descriptions arranged systematically, meaning that the secondary data obtained will be linked with each other tailored to the problems studied, so as a whole is a unified whole in accordance with the needs of research.

\section{PROBLEMS}

1. What is the agreement between the Government of Indonesia and PT. Newmont Nusa Tenggara so it is said to have happened Default of the contents of the agreement? 
2. How are the legal remedies carried out in relation to Default and the application of the law?

\section{DISCUSSION}

A. Default Against the Contents of Agreement Between the Government of Indonesia and PT. Newmont Nusa Tenggara

On December 2, 1986, the Government of Indonesia signed a work contract with PT. Newmont Nusa Tenggara (PT NNT) where in the formation of such contracts refers to RI Law no. 11 of 1967 on the Basic Provisions of Mining. One such inner clause is as contained in Article 24 paragraph (3) of the Contract of Work that PT. NNT shall ensure that shares owned by foreign investors will be offered for sale or publication, firstly to the Government and secondly (if the Government does not accept the offer within 30 days from the date of the offer), to the Indonesian Citizen ( WNI) or Indonesian Company controlled by Indonesian citizen. In reality the contents of the agreement relating to the clause in the Contract of Work are concerning the divestment of shares for the Government of Indonesia gradually that is not working properly, where the mining company fails to perform the obligation of share divestment in accordance with the Contract of Work which has been agreed. This has led to a dispute between the two parties, with the Government of Indonesia bringing the settlement of the matter to the Arbitration Institute.

In the contract of work agreement signed between the Government of Indonesia and PT. Newmont Nusa Tenggara, on page 1 of the contract of work has explicitly agreed and acknowledged that:

1) All mineral resources contained within the jurisdiction of the Republic of Indonesia, including offshore areas are the national wealth of the Indonesian nation and the Government intends to develop all the mining potentials within its territory.

2) The Government intends to promote the economic development of the people of Indonesia and therefore wishes to encourage and enhance the exploration and development of mineral resources to be found in commercial amounts of ore deposits, to carry out the necessary efforts, in accordance with the interests of the people and government requirements, to enable the development of sediment ore and the conduct of the said mining business activities and the implementation of the mining business activities concerned.

3) Through mining business activities, the Government intends to create growth centers for regional development, create more employment opportunities, encourage and develop local businesses, and to ensure that skills, knowledge and technology are transferred to Indonesian citizens, obtaining basic data related to state mineral resources, protect and rehabilitate the natural environment of Indonesia's subsequent development.

4) The Company, through Newmont Mining Corporation Ltd. a company incorporated in the State of Delware, USA, has or may obtain proven information, knowledge, experience and technical and financial capabilities and other resources to implement the General Inquiry program, Further exploration, development, development, mining, processing and sales shall be established, and prepared to proceed in such directions in accordance with the terms and conditions set forth in this Agreement and;

5) The Government and the Company are willing to cooperate in the development of mineral resources based on the laws and regulations of the Republic of Indonesia, in particular Law Number 11 Year 1967 concerning Mining Principles and Law Number 1 Year 1967 concerning Capital Investment Foreigners, as well as legislation and regulations relating to it.

One clause in this Contract article 24 under the title of National Interest Promotion paragraph (3), paragraph (4) and paragraph (5) Contract of Work that PT. NNT must ensure that shares owned by foreign investors will be offered for sale or publication, firstly to the government and second (if the government does not accept the offer within 30 days of the offer date), to Indonesian citizens or Indonesian companies controlled by Indonesian citizens. In article 24 paragraph (3) The Contract of Work between PT NNT and the Government stated that PT. NNT must ensure that shares owned by foreign investors will be offered for sale or publication, firstly to the government and second (if the government does not accept the offer within 30 days of the offer date), to Indonesian citizens or Indonesian companies controlled by Indonesian citizens.

In Article 24 paragraph (4) of the Contract of Work shall be stipulated on the obligatory contractual divestment provisions that should be implemented. PT NNT operational activities commenced on January 1, 2000, referring to Article 24 paragraph (4), divestment obligation commenced in the fifth year of 2006, and so on in 2010, the divestment obligation has reached $51 \%$.

The divestment is planned gradually and for 5 years, which should fall in 2006-2010, the fact that the contents of the agreement related to the clauses in the Contract of Work concerning the divestment of shares for the Government of Indonesia gradually is not working properly, where the mining company failed to implement the obligation to divest the shares in accordance with the agreed Contract of Work.

\section{B. The legal efforts undertaken by the Government of Indonesia relating to Default and Application of the Law.}

Government sued PT. NNT to the International Arbitration on March 3, 2008, there are two parties to this dispute:

1) The Government of the Republic of Indonesia as Plaintiff.

2) PT. Newmont Nusa Tenggara as Defendant.

The Government of Indonesia proposes two demands:

1) Requesting the Arbitration Panel to decide that the government may terminate Newmont's contract of employment on the grounds that the company has defaulted the default alias;

2) If termination can not be made, the Government shall request the Arbitration to order PT. NNT to sell the shares according to the letter of the Director General of Minerals of Coal and Geothermal related to the defaults. The contents of the letter of the Director General of Minerba Pabum were referred to by the Arbitration in 
determining their decision regarding the implementation of the divestment.

On the same day, Newmont also filed a lawsuit against the government. On July 11, 2008, Newmont proposed an additional arbitration related to the $7 \%$ divestiture required by the Contract of Work.

The Government of Indonesia put forward two demands, namely:

Instead, Newmont requested the arbitration party to declare that it was not negligent which could result in termination of the contract. Requesting Arbitration determines whether the first right of government refusal is no longer valid. For that reason, Newmont can sell its shares to the desired party.

Through a long process, the International Arbitration Council finally issued five final decisions on March 31, 2009 which won the Government of Indonesia. On March 31, 2009, the Government of Indonesia finally won a lawsuit over the PT NNT divestment case in International Arbitration. The United Nations Commission on International Trade Law and the Arbitral Tribunal (Arbitral Tribunal) consisting of internationally known panels, ordered PT NNT to implement the provisions of Article 24 paragraph (3) of the Contract of Work.

They also stated that PT. NNT has defaulted (breach of agreement), ordered to PT. NNT to divest $17 \%$ of the shares, which consist of $3 \%$ and $7 \%$ divestment in 2006 to the local government while for $20087 \%$ to the Government of the Republic of Indonesia. All such obligations shall be effected within 180 days after the date of the award of the Arbitration. In addition, the divested shares must be free of lien (clean and clear) and the source of funds for the purchase of shares is not a matter of PT NNT.

Newmont should also reimburse the costs incurred by the government for arbitration and must be paid within 30 days after the date of the award. The mining company headquartered in Denver, Colorado is required to pay the government's cost for arbitrage proceeds of US \$ 1.8 million.

From the results of the examination, both from witnesses and proof of letter, the Arbitration Council has established a decision on the dispute on divestment between the Government of Indonesia and PT. Newmont Nusa Tenggara. The verdict was set on March 31, 2009. The contents of the decision include the following:

PT. Newmont Nusa Tenggara is required to ensure that shares to be transferred / sold to the Government of Indonesia in accordance with Article 24 Paragraph (3) of the Contract of Work are exempt from pledge. PT. Newmont Nusa Tenggara is required to divest shares of $3 \%$ (three percent) in 2006; and 7\% (seven percent) in 2007 to the West Nusa Tenggara Provincial Government of West Sumbawa Regency, Sumbawa, or companies designated by the Regional Government. The arrangement of fund resources made by the Regional Government and / or its designated company is not an affair of PT. Newmont Nusa Tenggara.

About 7\% (seven percent) of divested shares in 2008. PT. Newmont Nusa Tenggara is obligated to deliver the shares to the government, ie the Government of Indonesia or Regional Government or company appointed by the Government of Indonesia or Regional Government if, after the approval of the price of the delivery of shares, the Government exercises its rights under the provisions of Article 24 Paragraph (3) Contract of Work. PT. Newmont Nusa Tenggara is granted a period of 180 days, from the decision to divest the shares to the Government of Indonesia.

PT. Newmont Nusa Tenggara is ordered to pay to the Government of the Republic of Indonesia within 30 days after the notification of this decision amounting to USD 190,306.25 for arbitration fees, plus 6\% (six percent) per annum interest as of November 12, 2008. PT. Newmont Nusa Tenggara is ordered to pay to the Indonesian government within 30 days after the notification of this decision amounting to USD 1,658,243 for representative fees and legal aid.

In 2009, the Central Government gave West Nusa Tenggara (NTB) Local Government an opportunity to purchase 24 percent NNT divestment shares. Thus, 24 percent of Newmont's shares are now controlled by PT MDB, a joint venture of PT Multi Capital and PT Daerah Maju Bersaing (DMB). PT Multi Capital is a subsidiary of PT Bumi Resources Minerals Tbk, under the Bakrie Group. DMB is a joint venture company of NTB provincial government, West Sumbawa regency, and Sumbawa regency.

The structure of share ownership in PT. NNT after divestment to $49 \%$ owned Nusa Tenggara Partnership, 24\% PT. Multi Daerah Bersaing, 17.8\% PT .. Pukuafu Indah, and $2.2 \%$ owned by PT Indonesia Masbaga Investama. The remaining $7 \%$ shares of PT NNT are to be divested.

On May 11, 2011 the Government through the Government Investment Center (PIP) signed the purchase agreement for the last 7\% stake divestment of PT. NNT for the 2010 period worth US \$ 246.8 million. Minister of Finance Agus Martowardojo representing the government appointed Government Investment Company (PIP) to buy $7 \%$ shares of PT. NNT conducted with the signing of a Sales Purchase Agreement (SPA). The signing of the SPA was conducted on May 6, 2011 between Nusa Tenggara Partnership B. V. (Newmont Mining Corporation shareholder in PT Newmont Nusa Tenggara together with Sumitomo Corporation of Japan) with Government Investment Center (PIP) as the government representative for the purchase of the remaining shares divestment of PT. Newmont Nusa Tenggara (NNT) at 7 percent. Purchase of $7 \%$ of NNT's remaining shares divestment by PIP is considered by the House to violate the law because it uses APBN, BPK's opinion is also the same, because the DPR is strengthened by BPK, the purchase of Newmont shares must be approved by Parliament for using APBN funds through PIP,

Minister of Finance, until finally settled in the Constitutional Court. The President through the Minister of Finance filed a lawsuit against the Constitutional Court related to the dispute over inter-state authority in February 2012. The Constitutional Court (MK) issued a decision No. 2 / SKLN-X / 2012 which declared rejected the government's request. With this Constitutional Court decision, the purchase of $7 \%$ of Newmont divestment shares must be through the permit of the Parliament. Amid the uncertainty of the government's stance to buy $7 \%$ of PT. NNT, PIP insisted to buy $7 \%$ stake in PT. NNT. This is evident from the continuous extension of the SPA by amending five times. 
The second amendment of the SPA was undertaken by the Government Investment Center and Nusa Tenggara Partnership B.V. by signing a 7 percent share divestment of PT. Newmont Nusa Tenggara on Wednesday, May 2, 2012. The signing was done by PIP Head Soritaon Siregar, with Blake Rhodes and Toru Tokuhisa from Nusa Tenggara Partnership B.V. at the PIP office in Jakarta. The background of the 2nd amendment is due to the fact that the effective terms agreed in the Amendment of Sale and Purchase Agreement signed as of 3 November 2011 have not been fulfilled. The 2nd Amendment is intended to extend the period of effective fulfillment of such purchase agreement until 6 August 2012.

The 3rd Amendment of SPA was undertaken by the Government Investment Center and Nusa Tenggara Partnership B.V. by signing the sale and purchase agreement of the divestment shares 7 (seven) Percent Share of Divestment of PT. Newmont Nusa Tenggara 2010 on Monday, August 6, 2012. The signing was done by PIP Head Soritaon Siregar with Blake Rhodes and Toru Tokuhisa from Nusa Tenggara Partnership B.V. at PIP office, Graha Mandiri, Jalan Imam Bonjol 61, Jakarta. This 3rd Amendment is conducted considering that to date the effective terms agreed in Amendment of Sale and Purchase Agreement signed on 3 November 2011 have not been fulfilled. With this 3rd Amendment, Government Investment Center and Nusa Tenggara Partnership B.V. agrees to extend the period of effective fulfillment of such sale agreement until October 25, 2012 in order to allow time for both parties to act in good faith to fulfill their respective obligations.

The 4th Amendment of SPA is done by Government Investment Center (PIP) and Nusa Tenggara Partnership (NTP) BV by signing a divestment agreement of 7 (seven) Percent Share Divestment shares of PT. Newmont Nusa Tenggara 2010 on 24 October 2012.23 With this 4th Amendment, PIP and NTP BV have agreed to extend the effective terms of the purchase agreement by 31 January 2013 to allow both parties time to act in good faith to fulfill their respective obligations -something.

The 5th Amendment of SPA was undertaken by the Government Investment Center and Nusa Tenggara Partnership B.V. by signing the sale and purchase agreement of the divestment shares 7 (seven) Percent Share of Divestment of PT. Newmont Nusa Tenggara 2010 on Thursday, January 31, 2013. The signing was done by PIP Head Soritaon Siregar, together with Blake Rhodes and Toru Tokuhisa from Nusa Tenggara Partnership B.V. at PIP office, Graha Mandiri, Jalan Imam Bonjol 61, Jakarta. The 5th Amendment is conducted considering that to date the effective terms agreed in Amendment of Sale and Purchase Agreement signed on October 24, 2012 have not been fulfilled. With this 5th Amendment, the Government Investment Center and Nusa Tenggara Partnership B.V. agrees to extend the period of effective fulfillment of such purchase agreement until April 26, 2013 to allow time for both parties to act in good faith to fulfill their respective obligations. The approval of the 5th Amendment was underpinned by a strong desire from Nusa Tenggara Partnership B.V. and Government Investment Center to realize sale and purchase agreement 7 Percent Share of Divestment PT. NNT Year 2010. With the obligations imposed on PT.NNT, the case is recognized to have occurred Wan-achievement, and in fact law enforcement has been done through the institution of Arbitration. The legal action taken by the Indonesian government by suing Newmont to international arbitration is appropriate and in accordance with the agreement contained in the contract of work agreement.

Although in his defense the PT. NNT denies allegations of infringement by showing some evidence that Newmont shares are in a position of mortgage so that it becomes an obstacle and causes the implementation of the divestment obligations not to be executed but the arbitrator who leads the arbitration trials in this dispute ignores the arguments proposed by the PT . NNT so that the arbitrator is able to produce objective rulings and in accordance with the principles adhered to by arbitration.

\section{CONCLUSIONS}

Deafault conducted by PT. Newmont Nusa Tenggara with the uncompleted divestiture clause, thus the Government of Indonesia is entitled to prosecute against the unfulfilled obligations.

The legal effort made by the Government of Indonesia is correct based on the understanding of the contents of Article 21 of the Contract of Work between the Government of Indonesia and PT. Newmont Nusa Tenggara. Furthermore, referring to Article 1 point 9 of Law N0. 30 of 1999, the arbitration award between the Government of Indonesia and PT Newmont Nusa Tenggara is the International Arbitration Ruling because under the arbitration procedure of the United Nations Commission on International Trade Law (UNCITRAL), and the Arbitral Tribunal consisting of internationally known panels with using the basic rules of the United Nations Commission on International Trade Law (UNCITRAL), the presence of foreign arbitrators, then indicating the existence of foreign elements of this arbitration can be said also that the arbitration is an international arbitration.

\section{REFERENCES}

[1] Ilmar Amirudin, Hukum Penanaman Modal Di Indonesia, Penerbit Prenada Media, Jakarta, 2004,

[2] Dokumen Kontrak Karya Antara Pemerintah Republik Indonesia dan PT. Newmont Nusa Tenggara, in press.

[3] Mutofa, Syahrul, \& Mustofa, Saipul, Kedudukan Hukum Negara Dalam Perjanjian Kontrak Karya (Studi Perjanjian Kontrak Karya Pertambangan Antara Pemerintah RI dengan PT NNT), Makalah Tahun 2012, UI., in press.

[4] Sekretaris Jenderal Pusat Investasi Pemerintah, Pemerintah Beli Disvestasi Terakhir NNT 7 Persen, Keterangan Pers No PERS002/IP/2011.

[5] Sekretaris Jenderal Pusat Investasi Pemerintah, Penandatangan Amandemen Ke-3 Perjanjian Jual Beli 7 Persen Saham Divestasi PT Newmont Nusa Tenggara, Siaran Pers NomorPERS-01/IP/201.

[6] Nin Yasmin Lilasih, Analisis Penyelesaian Sengketa Divestasi Saham melalui Arbitrase Internasional (Sengketa Pemerintah Indonesia dengan PT Newmont Nusa Tenggara), http://ninyasmine.wordpress.com/2013/02/18/analisis-penyelesaiansengketa-divestasi-saham-melalui-arbitrase-internasional-sengketapemerintah-indonesia-dengan-pt-newmont-nusa-tenggara/.

[7] Sumber Situs Resmi PT.Newmont Nusa Tenggara, http://www.ptnnt.co.id/id/ sejarah.aspx.

[8] Amandemen ke-2 Divestasi Newmont Ditandatangani, http://lipsus.kompas.com/ topikpilihanlist/2133/1/100.hari.jokowibasuki/read/xml/2012/05/03/1 1425827/Amandemen.ke-2. Divestasi.Newmont. 